\title{
PENGENALAN DAN PELATIHAN BERHITUNG DENGAN JARIMATIKA DAN SEMPOA DI SDN 10 AMPENAN
}

\author{
Dewi Pramita ${ }^{1}$ \\ 1Pendidikan Matematika, Universitas Muhammadiyah Mataram, mitha_dhewi@yahoo.com
}

\begin{abstract}
ABSTRAK
Abstrak: Pengenalan dan pelatihan berhitung dengan sempoa di SDN 10 Ampenan bertujuan untuk mengembangkan kemapuan berpikir dan ketertarikan siswa dalam matematika. Kegiatan ini dilaksanakan selama dua minggu, dengan durasi pertemuan selama 60 menit setiap pertemuannya. Siswa yang mengikuti kegiatan adalah siswa yang dianggap mampu mengikuti pelatihan, berasal dari kelas empat, lima dan enam. Materi yang diajarkan terlebih dahulu yaitu tentang jarimatika dan rumus-rumus yang dipergunakan, barulah kemudian diajarkan menggunakan sempoa. Sempoa yang dipakai adalah sempoa dengan lima biji atau manik, satu manik diatas dan empat manik dibawah garis pembatasnya. Respon siswa sangat baik dalam pelaksanaan kegiatan dikarenakan sempoa merupakan hal baru bagi mereka, selain itu dengan diajarkan sempoa siswa menjadi lebih bersemangat dan fokus dalam mengikuti pelajaran matematika dikelas.
\end{abstract}

Kata Kunci: Sempoa.

Abstract: The aims of introduction and numeracy training with abacus in SDN 10 Ampenan is to develop students' thinking and interest in mathematics.this activity is held for two weeks, with duration of 60 minutes per meeting.student whom follow the activities are student who have capability, class four, five and six. The first taught material that is about the jarimatica and the formula used, then taught using the abacus.the abacus used is an abacus with five seeds or beads, one bead above and four beads below the dividing line.student response in the implementation of the activities are very excellent because abacus is new for them. Beside with taught abacus, students become more exited and focus in following the math lessons in classroom..

Keywords: Abacus.

Riwayat Artikel: Diterima: 12-11-2017, Disetujui: 16-12-2017 


\section{A. LATAR BELAKANG}

Perkembangan zaman dan ilmu pengetahuan yang semakin maju menuntut kita untuk dapat menyesuaikan diri dengan keadaan tersebut. Menyesuaikan diri yang dimaksud adalah mampu mengembangkan potensi diri dalam berbagai aspek baik ilmu pegetahuan, pemikiran, sikap mental dan keterampilan. Potensi dalam diri anak dapat dilihat dari gejalanya yang mungkin berupa ucapannya atau perbuatannya. Salah satu potensi penting yang dimiliki anak didik (siswa) adalah berpikir. Suatu potensi yang perlu dikembangkan secara tepat dan bertahap, meningkat kearah yang bermanfaat untuk menghadapi hidup masa depannya (Soedjadi, 2007).

Sempoa atau dikenal dengan mental aritmatika adalah salah satu media untuk mengembangkan kemampuan berpikir dan berhitung dalam matematika serta mampu menyeimbangkan kemampuan otak kanan dan otak kiri. Sempoa sudah dipelajari maupun dikembangkan di Indonesia. Media ini sangat popular di kalangan masyarakat keturunan cina (tionghoa), Jepang, Taiwan, Korea dan dibeberapa kalangan masyarakat pribumi. Dengan menggunakan media ini, kita tidak membutuhkan waktu yang lama untuk mencari hasil penjumlahan, pengurangan, perkalian dan pembagian tanpa menggunakan alat bantu kalkulator.

Mempelajari sempoa melatih kemampuan berpikir, mengingat berbagai rumus yang digunakan untuk melakukan operasi-operasi hitung dan tentunya kecepatan dalam berhitung serta memperoleh hasil akhir. Mempelajari sempoa tidak lepas dari jarimatika, sebagai langkah awal pengenalan sempoa. Salah satu contohnya, apabila menggunakan jarimatika (jari) tangan kanan menunjukan angka satuan dan tangan kiri menunjukan angka puluhan dan apabila menggunakan kedua tangan merupakan campuran antara puluhan dan satuan. Angka 25, pada jarimatika menggunakan jari tangan kiri 20 (jari kelingking dan jari manis) dan tangan kanan 5 (jempol). Sedangkan apabila diartikan secara awam, jari kelingking, jari manis dan jempol dianggap menunjukan angka tiga. Jika dikaitkan dalam sebuah operasi $25-2=$ ?, mengurangi dua pada angka 25 dengan menggunakan rumus teman kecil yaitu menutup jempol (tangan kanan) membuka dua jari lainnya (jari kelingking dan jari manis). Dengan demikian diperolehlah hasil 22 hal ini ditunjukan dengan jari kelingking dan jari manis di tangan kanan dan di tangan kiri.

Contoh tersebut merupakan salah satu contoh sederhana, bagaimana jika soal yang ditemui berupa $2+6-3+35-7+2-1+2-4+30+20+7-$ 2 = dibutuhkan waktu yang lebih lama untuk mehitung hasilnya. Dengan sempoa akan memudahkan dan meminimalkan waktu berhitung soal-soal yang demikian. Jarimatika dan sempoa lebih mudah diajarkan pada anakanak usia sekolah dasar, karena kemampuan otak untuk merespon dan mengingat masih bagus. Mempelajari jarimatika dan sempoa memberi dampak positif bagi perkembangan otak dan mental anak, maka dari itu perlu diadakan pengenalan dan pelatihan bagi anak-anak usia sekolah dasar.

Sekolah yang tempat pelaksanaan pengabdian yaitu SDN 10 Ampenan yang merupakan salah satu sekolah yang cocok untuk diberikan pelatihan sempoa. Berdasarkan wawancara terhadap guru sekolah, tingkat kemampuan berhitung dan ketertarikan siswa terhadap mata pelajaran matematika cukup rendah. Dengan tujuan agar siswa dapat 
mengembangkan kemampuan berpikir dan ketertarikannya terhadap matematika.

\section{B. KAJIAN PUSTAKA}

Sempoa paling tua ditemukan di Mesopotamia di pulau Salamis dan Hiroglif Fir'aun di Mesir. Mulanya sebagai alat hitung yang sangat sederhana. Saat itu, manusia mengganti butiran-butiran dari tanah sebagai pengganti setiap jari, dan dibuat jalur di tanah untuk menggantikan tangan sebagai pangkal jari. Butiran tanah inilah yang dalam bahasa Yunani disebut abax yang kemudian terkenal dengan istilah abacus (IMA, 2014 ).

Sempoa yang digunakan awalnya bermanik dua diatas lima dibawah, seiring dengan perkembangannya menjadi sempoa yang bermanik satu diatas dan empat dibawah seperti sempoa yang kita gunakan sekarang. Kemudian berkembang ilmu sempoa bayangan (mental aritmatika).

Banyak manfaat yang diperoleh dengan mempelajari sempoa. Diantaranya (cmaindo, 2016) sebagai berikut: menyeimbangkan otak kanan dan otak kiri. Melatih daya imajinasi dan kreatifitas, meningkatkan konsentrasi belajar. Pada saat mempelajari sempoa, siswa latih untuk berkonsentrasi, sehingga mampu menyelesaikan perhitungan aritmatika dengan cepat dan cermat. Dengan demikian siswa akan terbiasa fokus dengan apa yang sedang ditekuninya. Siswa juga dilatih mengkoordinasikan kerja otak kiri dan kanan, karena pada saat menghitung dengan sempoa siswa harus bisa membayangkan sempoa tanpa melihat langsung sempoa tersebut. Disaat yang bersamaan siswa harus mengingat rumus-rumus dan perhitungan yang akan ataupun sedang ia kerjakan.

Menyeimbangkan kerja otak kanan dan otak kiri mampu mengembangkan kerja otak secara maksimal. Akan tetapi, sangat disayangkan pedidikan saat ini lebih melatih pendayagunaan kemampuan otak kiri, sedangkan otak kanan kurang begitu tersentuh (Deporter, 2010). Hal ini diakibatkan teknologi canggih yang semakin berkembang sehingga memudahkan kehidupan kita, namun secara tidak kita sadari semua kemudahan ini lambat laun mematikan kerjasama kedua otak kiri dan kanan.

\section{METODE PELAKSANAAN}

Kegiatan dilakukan dengan memberikan pengenalan pada siswa dan guru, baru kemudian diadakan pelatihan khusus bagi siswa. Kegiatan yang dilakukan diantaranya mensosialisasikan kepada pihak sekolah (kepala sekolah dan guru) tentang jarimatika dan sempoa, barulah meminta beberapa perwakilan siswa untuk mengikuti pelatihan tersebut. Siswa dipilih secara acak dari beberapa kelas yang dianggap mampu untuk mengikuti kegiatan tentunya dengan izin dari wali murid itu sendiri. Kegiatan dilaksanakan selama dua minggu dengan durasi pelaksanaan selama 60 menit setiap pertemuan setelah jam sekolah berkhir. Kegiatan ditargetkan diikuti oleh 25 orang siswa dari berbagai macam tingkatan, ada yang berasal dari kelas 4 , 5, dan 6 . Namun pada saat pelaksanaan hingga akhir kegiatan diikuti oleh 20 orang siswa. 
Diawal pelaksanaan sosialisasi kepada kepala sekolah dan guru dilaksanakan pada 7 April 2014 pada pagi hari dan 9 April 2014 pagi hari dilakukan sosialisasi pada siswa dan pemilihan siswa yang akan mengikuti kegiatan secara acak. Pada pertemuan berikutnya Pelatihan dilakukan didalam kelas seusai jam sekolah yaitu pukul 16.00 -17.00. Pada tahap awal pengenalan, siswa tidak langsung diberikan alat sempoa. Siswa terlebih dahulu diperkenalkan dengan jarimatika dan rumus-rumus yang dipergunakan, barulah kemudian diajarkan menggunakan sempoa. Sempoa yang digunakan adalah sempoa dengan lima biji atau manik, satu manik diatas dan empat manik dibawah pembatas.

\section{HASIL DAN PEMBAHASAN}

\section{Pelaksanaan Kegiatan}

Kegiatan dilaksanakan selama dua minggu dengan durasi pelaksanaan selama 60 menit setiap pertemuan setelah jam sekolah berkhir. Kegiatan ditargetkan diikuti oleh 25 orang siswa dari berbagai macam tingkatan, ada yang berasal dari kelas 4, 5, dan 6. Namun pada saat pelaksanaan hingga akhir kegiatan diikuti oleh 20 orang siswa. Kegiatan dilaksanakan dalam rung kelas 6 selama dua minggu sebayak 12 kali pertemuan, dua pertemuan untuk sosialisasi dan sepuluh kali pertemuan untuk pelatihan siswa.

\section{TABEL 1}

Jadwal pelaksanaan kegiatan

\begin{tabular}{|c|c|c|c|}
\hline No & Waktu & Jenis Kegiatan & Pemateri \\
\hline 1 & $\begin{array}{l}\text { Hari pertama } \\
\left(16.00^{-17.00)}\right.\end{array}$ & Pengenalan jarimatika & Dewi Pramita \\
\hline 2 & $\begin{array}{l}\text { Hari kedua } \\
(16.00-17.00)\end{array}$ & Rumus teman kecil I & Dewi Pramita \\
\hline 3. & $\begin{array}{l}\text { Hari ketiga } \\
(16.00-17.00)\end{array}$ & Rumus teman kecil II & Dewi Pramita \\
\hline 4 & $\begin{array}{l}\text { Hari keempat } \\
(16.00-17.00)\end{array}$ & Rumus teman besar I & Dewi Pramita \\
\hline 5 & $\begin{array}{l}\text { Hari kelima } \\
(16.00-17.00)\end{array}$ & Rumus teman besar II & Dewi Pramita \\
\hline 6 & $\begin{array}{l}\text { Hari keenam } \\
(16.00-17.00)\end{array}$ & Pengenalan Sempoa & Dewi Pramita \\
\hline 7 & $\begin{array}{l}\text { Hari ketujuh } \\
(16.00-17.00)\end{array}$ & $\begin{array}{c}\text { Penggunaan rumus } \\
\text { teman kecil I pada } \\
\text { sempoa }\end{array}$ & Dewi Pramita \\
\hline 8 & $\begin{array}{l}\text { Hari kedelapan } \\
\left(16.00^{-17.00)}\right.\end{array}$ & $\begin{array}{l}\text { Penggunaan rumus } \\
\text { teman kecil II pada } \\
\text { sempoa }\end{array}$ & Dewi Pramita \\
\hline 9 & $\begin{array}{l}\text { Hari } \\
\text { kesembilan } \\
(16.00-17.00)\end{array}$ & $\begin{array}{l}\text { Penggunaan rumus } \\
\text { teman besar I pada } \\
\text { sempoa }\end{array}$ & Dewi Pramita \\
\hline 10 & $\begin{array}{l}\text { Hari kesepuluh } \\
(16.00-17.00)\end{array}$ & $\begin{array}{l}\text { Penggunaan rumus } \\
\text { teman besar II pada } \\
\text { sempoa }\end{array}$ & Dewi Pramita \\
\hline
\end{tabular}




\section{Hasil dan pembahasan}

Pelaksanaan pengabdian ini berjalan lancar tanpa hambatan sedikitpun. Antusias anak-anak, guru, dan orang tua dalam kegiatan ini sangat besar. Hal ini terlihat dari pemberian izin dari kepala sekolah dan guru, izin dari wali siswa sehingga siswa hadir dan mengikuti kegiatan hingga akhir meski kegiatan ini menyebabkan siswa harus datang dua kali sehari ke sekolah selama dua minggu. Namun ada beberapa masalah yang ditemukan dalam kenyataan setelah dilakukan pelatihan, antara lain:

1. Beberapa siswa tidak mampu mengikuti dengan baik kegiatan ini, hal ini disebabkan daya tangkap atau kemampuan menerima pelajaran cukup rendah. Tidak semua siswa mengalami hal tersebut, ada juga siswa yang mampu merespon dengan baik materi ataupun rumus-rumus yang diajarkan dalam menggunakan jarimatika maupun sempoa. Hal ini dapat terlihat pada saat siswa dapat menjawab dengan cepat dan tepat soal-soal yang diberikan. Soal-soal yang diberikan masih dalam bentuk yang sederhana dan operasi aritmatika yang diajarkan hanya penjumlahan pengurangan dengan jarimatika dan sempoa saja. Dengan mempertimbangkan bahwa kemampuan siswa di sekolah tidak tergolong dalam kemampuan tinggi, dan rekomendasi dari guruguru kelas mereka.

Beberapa contoh soal yang diberikn pada siswa, diantaranya (Anonim ,2010):

a. $4+5-1-2+3-4-5=0$

b. $2+5-6+10-2-4+15-17+25-3-1=24$

c. $10-4-3-1+7+20+10-13-12=14$

d. Dan lain-lain

Pemberian soal dilakukan secara lisan dengan intonasi mulai dari lambat, sedang hingga cepat, semakin cepat soal diberikan semakin cepat pula siswa untuk berhitung. Ada siswa yang bias mengikuti ada juga siswa yang tertinggal apabila diberikan soal dengan intonasi yang cepat. Dengan perlakuan yang demikian memicu semangat siswa untuk berlomba-lomba menjawab soal yang diberikan meskipun terkadang kebingungan dengaan rumus-rumus dan alat sempoa yang dipergunakan. Jari siswa masih kaku dalam memainkan manik-manik sempoa. Hal ini juga yang menghambat kecepatan siswa dalam menjawab.

2. Siswa bahkan guru banyak yang tidak mengenal sempoa bahkan belum pernah melihat alat tersebut. Artiya, sempoa masih merupakan hal yang asing atau baru bagi mereka. Seperti yang kita ketahui, sempoa sudah dipelajari di Indonesia sejak bertahuntahun yang lalu meski pada awalnya hanya dipelajari oleh masyarakat keturunan saja.

Dampak yang terjadi di dalam kelas selama pelatihan, berdasarkan pengamatan guru. Siswa menggunakan jarimatika sebagai alat bantu menghitung yang dianggap lebih mudah penggunaanya dibanding sempoa karena masih kaku memainkan manik-manik. Dengan adanya pelatihan ini siswa menjadi lebih fokus dan semangat saat pelajaran matematik dikelas. 


\section{E. SIMPULAN DAN SARAN}

Berdasarkan kegiatan pengabdian yang telah dilakukan maka simpulan yang diperoleh bahwa dengan mempelajari jarimatika dan sempoa dapat membantu siswa dalam berhitung lebih cepat dan cermat, serta meningkatkan semangat belajar. Hal ini dapat disimpulkan berdasarkan pengamatan guru dari masing-masing siswa, yang berpendapat bahwa ada perubahan dalam sikap belajar siswanya, meskipun siswa lebih suka menggunakan jarimatika dibanding sempoa.

Adapun saran yang dapat disampaikan adalah: perlu diadakan pelatihan lanjutan, karena keterbatasan siswa dan waktu. Materi sempoa pada operasi perkalian dan pembagian belum disertakan dalam materi pelatihan. Penggunaan mental aritmatika juga belum diajarkan pada siswa Karen aketerbatasan siswa dalam menggunakan sempoa yang masih kaku dan lambat.

\section{UCAPAN TERIMA KASIH}

Tim penulis mengucapkan terima kasih kepada Lembaga Pengabdian Pada Masyarakat (LPPM) Universitas Muhammadiyah Mataram yang telah mendanai kegiatan pengabdian ini sehingga terlaksana dengan baik. Terima kasih kepada pihak sekolah terutama kepala sekolah dan guru-guru yang telah memberi izin dan mendukung terlaksananya kegiatan pengabdian ini, serta siswa-siswa elas 4,5 dan 6 yang telah mengikuti kegiatan dengan antusias.

\section{DAFTAR RUJUKAN}

[1] Anonim, Modul Sempoa Level 1 -5, Brainy Collage, Makassar, 2010.

[2] Cmaindo, Mengapa Belajar Sempoa Banyak Manfaatnya?, CMA Mental Aritmatika, WwW.cmaindo.com, diakses tanggal 30 Maret 2014.

[3] Deporter, B, and Hernacki, M, Quantum Learning, Kaifa, Bandung, 2010.

[4] IMA, Sejarah Sempoa, IMA global link Jateng \& DIY, www.ima-jateng-diy.com. Dikses tanggal 30 Maret 2014.

[5] Soedjadi, R, Masalah Kontekstual sebagai Batu Sendi Matematika Sekolah, Surabaya, 2007.

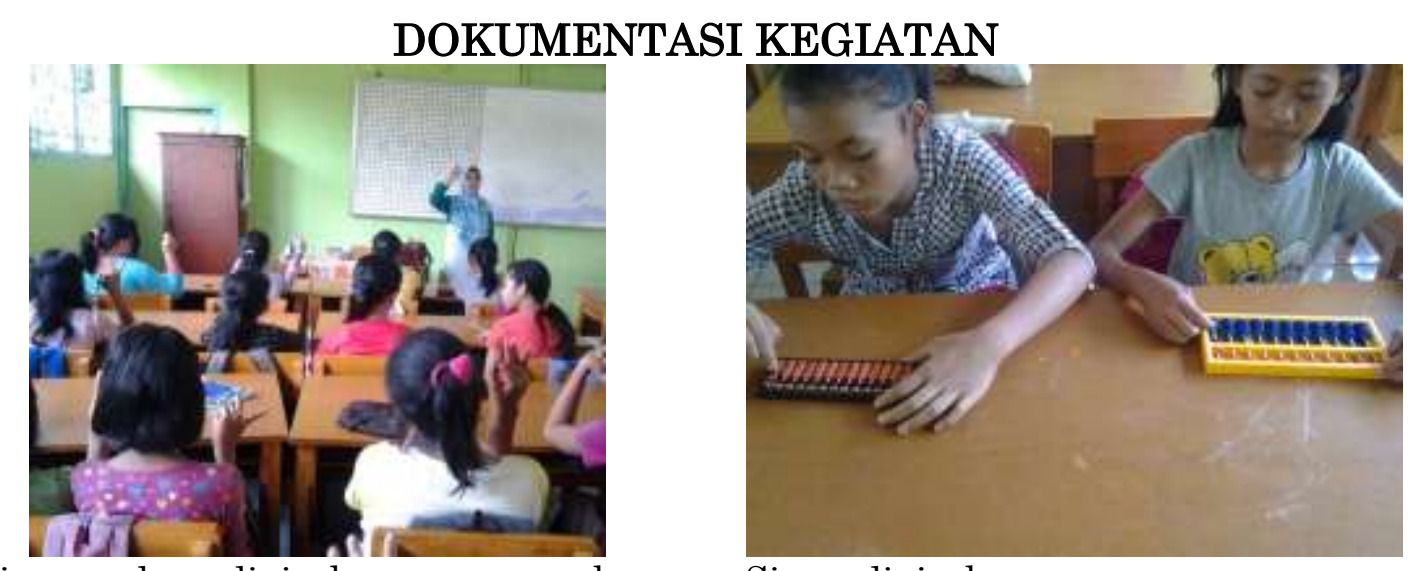

Siswa sedang diajarkan menggunakan jarimatika.

Siswa diajarkan penggunaan sempoa 